\title{
Pengaruh Preferensi Belanja Konsumen terhadap Perkembangan Pasar Ciputat di Kota Tangerang Selatan
}

\author{
Nurul Handayani, Kuswanto Nurhadi, dan Erma Fitria Rini \\ Program Studi Perencanaan Wilayah dan Kota \\ Fakultas Teknik \\ Universitas Sebelas Maret, Surakarta \\ Email: nurulhandyni@gmail.com
}

\begin{abstract}
Ciputat Market is a regional scale traditional market in South Tangerang. In 2002, the construction of shopping centers and modern shops began to grow slowly in the area of South Tangerang. The operation of shopping centers and modern shops are getting closer and outreach to the people, on the one hand it has made it easier for people to buy goods of daily needs, but on the other hand it can impact the development of the traditional market, because consumers have many choices places to shop. The problem of this study was about the changing of consumers shopping preference that can effect the development of Ciputat Market. The purpose of this study was to determine the effect of consumers shopping preferences towards the development of Ciputat Market in South Tangerang. The method used in this research is deductive with descriptive explanative technique analysis. While the data obtained is the result of field observations, questionnaires, and document research. The results of this study shows the preferences of consumer shopping in South Tangerang bases on the location of shopping vebues indicated a tendency to shop in other shopping venues rather than Ciputat market, while the development of the range of services markets tend to stagnate.
\end{abstract}

Keywords: shopping preferences, development of traditional markets

\section{PENDAHULUAN}

Pasar Ciputat merupakan pasar yang diarahkan untuk melayani kebutuhan penduduk di Kota Tangerang Selatan dan sekitarnya. Pada tahun 2002, pembangunan pusat perbelanjaan dan toko modern berskala lingkungan hingga regional mulai berkembang di Kota Tangerang Selatan yang pada masa itu masih berada di bawah administrasi Kabupaten Tangerang. Masyarakat Kota Tangerang Selatan memiliki semakin banyak pilihan tempat berbelanja yang tidak hanya menawarkan berbagai barang kebutuhan, tetapi juga kenyamanan dan pengalaman berbelanja yang berbeda. Preferensi masyarakat dalam memilih tempat berbelanja mulai mempertimbangkan aspek lain di luar keinginan untuk memenuhi barang kebutuhan. Pasar Ciputat sebagai sarana perdagangan dan jasa tradisional dengan fasilitas yang minim dan kondisi yang kurang tertata, tertinggal jauh dari toko modern yang unggul dari segi kenyamanan berbelanja. Preferensi konsumen dalam memilih tempat berbelanja dikhawatirkan tidak lagi mempertimbangkan Pasar Ciputat sebagai tujuan berbelanja. Keberlangsungan Pasar Ciputat sebagai sarana perdagangan dan jasa dapat terpengaruh oleh berubahnya preferensi konsumen dalam memilih tempat berbelanja.
Penelitian ini dilakukan untuk mengetahui bagaimana pengaruh preferensi belanja konsumen di Kota Tangerang Selatan terhadap perkembangan Pasar Ciputat dengan ruang lingkup waktu penelitian yaitu tahun 2002 hingga September 2016. Pada proses pemilihan tempat berbelanja, konsumen akan memilih tempat berbelanja yang sesuai dengan preferensinya. Preferensi tersebut akan menuntun konsumen ke tempat berbelanja yang dianggap cocok dengan keinginan konsumen dan menutup peluang tempat berbelanja lain yang tidak sesuai dengan keinginan konsumen untuk dikunjungi. Hal tersebut akan mempengaruhi perkembangan tempat berbelanja, dimana tempat berbelanja yang dipilih konsumen dapat meningkat perkembangannya sedangkan tempat berbelanja yang tidak dipilih konsumen dapat menurun perkembangannya.

\section{TINJAUAN PUSTAKA}

Perkembangan pasar adalah perubahan pada aspek-aspek fisik maupun non fisik pada pasar, khususnya perubahan yang dapat diukur, dengan perubahan yang cenderung menunjukkan peningkatan dari segi kualitas maupun kuantitas dibandingkan dengan kondisi sebelumnya. Sebuah pasar pada dasarnya 
dibangun untuk melayani penduduk pada cakupan wilayah tertentu. Kotler (dalam Sukriswanto, 2012) mengemukakan tingkatan skala pelayanan pasar berdasarkan radius pelayanan (market range) dan jumlah pengguna (threshold population). Untuk skala pelayanan pasar setara wilayah kecamatan, market range mencapai $7.500 \mathrm{~m}$ dengan jumlah threshold population 50.000-75.000 jiwa. Pada skala pelayanan pasar kota, market range hingga $10.000 \mathrm{~m}$ dan threshold population 250.000500.000 jiwa. Untuk pasar berskala regional memiliki market range hingga mencakup wilayah lokal dan regional dengan jumlah penduduk pendukung mencapai 500.000/750.000 jiwa.

Preferensi konsumen, khususnya pada tahap pemilihan tempat berbelanja, merupakan tahap dimana konsumen sudah melakukan pemilihan terhadap tempat berbelanja yang disenangi dibandingkan tempat lainnya, yang pada akhirnya menimbulkan niat untuk berbelanja dimana hal tersebut merupakan tahap kecenderungan konsumen untuk bertindak sebelum keputusan berbelanja dilaksanakan (Hidayati, 2010). Menurut hukum ekonomi keruangan Christaller (dalam Daldjoeni, 1992), konsumen menanggung ongkos angkutan untuk menuju ke tempat pusat dimana konsumen membeli barang kebutuhannya, sehingga jarak tempuh yang dinyatakan dalam biaya dan waktu sangat penting untuk dipertimbangkan. Hal tersebut kemudian menjadikan jangkauan (range) suatu barang ditentukan oleh jarak yang dinyatakan dalam biaya dan waktu pula. Konsumen cenderung memilih tempat pusat yang letaknya paling dekat untuk mendapatkan barang dan jasa yang dibutuhkan, mengingat faktor biaya dan waktu yang harus ditanggung oleh konsumen sendiri.

\section{METODE PENELITIAN}

Metode penelitian ini berisi ruang lingkup penelitian dan metode analisis yang digunakan untuk mengetahui pengaruh preferensi belanja konsumen terhadap perkembangan Pasar Ciputat.

\subsection{Ruang Lingkup}

Batasan area pada penelitian ini didasarkan pada radius pelayanan pasar berskala kota yang dikemukakan oleh Kotler (dalam Sukriswanto, 2012) yaitu sejauh $10.000 \mathrm{~m}$. Berdasarkan radius pelayanan tersebut, wilayah yang termasuk dalam jangkauan pelayanan Pasar Ciputat mencakup wilayah yang berada di dalam administrasi Kota Tangerang Selatan, Kota Tangerang, Provinsi DKI Jakarta, Kota Depok, dan Kabupaten Bogor. Peta jangkauan pelayanan Pasar Ciputat dalam skala kota berdasarkan RTRW Kota Tangerang Selatan Tahun 2011 - 2031 dapat dilihat dalam Lampiran 1.

Namun dalam penelitian ini, batasan area akan difokuskan pada wilayah administrasi Kota Tangerang Selatan. Wilayah studi yang akan diteliti adalah wilayah di dalam administrasi Kota Tangerang Selatan yang termasuk dalam jangkauan pelayanan Pasar Ciputat, meliputi seluruh kelurahan yang berada di Kota Tangerang Selatan berdasarkan RTRW Kota Tangerang Selatan Tahun 2011 2031. Peta wilayah studi dapat dilihat dalam Lampiran 2.

\subsection{Metode Analisis}

Penelitian untuk mengidentifikasi "Pengaruh Preferensi Belanja Konsumen terhadap Perkembangan Pasar Ciputat" ini menggunakan pendekatan deduktif, yaitu penelitian yang dimulai dengan mengkaji teori preferensi belanja dan perkembangan pasar guna mendapatkan arahan dalam menentukan kebutuhan data.

Variabel dalam penelitian ini adalah preferensi belanja konsumen berdasarkan kedekatan lokasi berbelanja, yang dinyatakan dalam jarak, yang biasanya ditempuh konsumen untuk menuju tempat berbelanja sebagai variabel bebas dan perkembangan jangkauan pelayanan Pasar Ciputat sebagai variabel terikat.

Teknik analisis data yang digunakan dalam penelitian ini yaitu:

\subsubsection{Analisis Deskripsi Naratif}

Analisis ini digunakan untuk mengetahui perubahan preferensi belanja konsumen dan perkembangan Pasar Ciputat dengan menggunakan perhitungan kuantitatif untuk mengidentifikasi adanya perubahan serta masukan dari teori terkait disertai dengan penjelasan bersifat deskripsi naratif.

\subsubsection{Analisis Deskripsi Eksplanatif}

Analisis ini digunakan untuk mengetahui pengaruh preferensi belanja konsumen terhadap perkembangan Pasar Ciputat dengan terlebih dahulu melakukan penilaian pada aspek 
preferensi konsumen yang dipaparkan dalam Tabel 1 dan penilaian pada aspek perkembangan pasar yang dijelaskan dalam Tabel 2.

Tabel 1. Penilaian Aspek Preferensi Belanja Konsumen

\begin{tabular}{|c|c|}
\hline Penilaian & Keterangan \\
\hline $\begin{array}{l}\text { Bertambah/ } \\
\text { tetap }\end{array}$ & $\begin{array}{l}\text { Ditinjau dari } \\
\text { perubahannya, preferensi } \\
\text { belanja konsumen dalam } \\
\text { memilih Pasar Ciputat } \\
\text { sebagai tempat } \\
\text { berbelanja cenderung } \\
\text { tetap atau mengalami } \\
\text { peningkatan }\end{array}$ \\
\hline Berkurang & $\begin{array}{l}\text { Ditinjau dari } \\
\text { perubahannya, preferensi } \\
\text { belanja konsumen dalam } \\
\text { memilih Pasar Ciputat } \\
\text { sebagai tempat } \\
\text { berbelanja cenderung } \\
\text { mengalami penurunan }\end{array}$ \\
\hline
\end{tabular}

Tabel 2. Penilaian Aspek Perkembangan Pasar

\begin{tabular}{|l|l|}
\hline Penilaian & Keterangan \\
\hline Meningkat/tetap & Ditinjau dari \\
& perubahannya, \\
& perkembangan Pasar \\
& Ciputat cenderung tetap \\
& atau mengalami \\
& peningkatan \\
\hline Menurun & Ditinjau dari \\
& perubahannya, \\
& perkembangan Pasar \\
& Ciputat cenderung \\
& mengalami penurunan \\
\hline
\end{tabular}

Setelah dilakukan penilaian pada masingmasing aspek tersebut, selanjutnya peneliti membentuk pola dan mencari kesepadanan antara aspek preferensi belanja konsumen sebagai variabel bebas dan aspek perkembangan pasar sebagai variabel terikat. Kesepadanan ini diidentifikasi melalui Tabel 3 yang menunjukkan hubungan antara dua variabel tersebut.

Tabel 3. Pengaruh Preferensi Belanja Konsumen terhadap Perkembangan Pasar Ciputat

\begin{tabular}{|l|l|l|}
$\begin{array}{l}\text { Perkemba- } \\
\text { ngan Pasar } \\
\begin{array}{l}\text { Preferensi } \\
\text { Belanja } \\
\text { konsumen }\end{array}\end{array}$ & $\begin{array}{l}\text { Meningkat/ } \\
\text { Tetap }\end{array}$ & Menurun \\
\hline & $\begin{array}{l}\text { Pengaruh I } \\
\text { Jumlah } \\
\text { konsumen yang } \\
\text { preferensinya } \\
\text { mendukung untuk }\end{array}$ & $\begin{array}{l}\text { Pengaruh II } \\
\text { yang preferensinya } \\
\text { mendukung untuk } \\
\text { berbelanja ke Pasar }\end{array}$ \\
\hline
\end{tabular}

\begin{tabular}{|c|c|c|}
\hline $\begin{array}{l}\text { Perkemba- } \\
\text { ngan Pasar } \\
\text { Preferensi }\end{array}$ & $\begin{array}{l}\text { Meningkat/ } \\
\text { Tetap }\end{array}$ & Menurun \\
\hline & $\begin{array}{l}\text { berbelanja ke } \\
\text { Pasar Ciputat } \\
\text { bertambah dan } \\
\text { perkembangan } \\
\text { Pasar Ciputat } \\
\text { mengalami } \\
\text { peningkatan } \\
\text { menunjukkan } \\
\text { bahwa preferensi } \\
\text { belanja konsumen } \\
\text { berpengaruh } \\
\text { terhadap } \\
\text { perkembangan } \\
\text { Pasar Ciputat) }\end{array}$ & $\begin{array}{l}\text { Ciputat bertambah } \\
\text { sedangkan } \\
\text { perkembangan } \\
\text { Pasar Ciputat } \\
\text { mengalami } \\
\text { peningkatan } \\
\text { menunjukkan } \\
\text { bahwa preferensi } \\
\text { belanja konsumen } \\
\text { tidak berpengaruh } \\
\text { terhadap } \\
\text { perkembangan } \\
\text { Pasar Ciputat) }\end{array}$ \\
\hline Berkurang & $\begin{array}{l}\text { Pengaruh III } \\
\text { Jumlah konsumen } \\
\text { yang } \\
\text { preferensinya } \\
\text { mendukung untuk } \\
\text { berbelanja ke } \\
\text { Pasar Ciputat } \\
\text { berkurang dan } \\
\text { perkembangan } \\
\text { Pasar Ciputat } \\
\text { mengalami } \\
\text { peningkatan } \\
\text { menunjukkan } \\
\text { bahwa preferensi } \\
\text { belanja konsumen } \\
\text { tidak berpengaruh } \\
\text { terhadap } \\
\text { perkembangan } \\
\text { Pasar Ciputat) }\end{array}$ & $\begin{array}{l}\text { Pengaruh IV } \\
\text { Jumlah konsumen } \\
\text { yang preferensinya } \\
\text { mendukung untuk } \\
\text { berbelanja ke Pasar } \\
\text { Ciputat berkurang } \\
\text { sementara } \\
\text { perkembangan } \\
\text { Pasar Ciputat turut } \\
\text { mengalami } \\
\text { penurunan } \\
\text { menunjukkan } \\
\text { bahwa preferensi } \\
\text { belanja konsumen } \\
\text { berpengaruh } \\
\text { terhadap } \\
\text { perkembangan } \\
\text { Pasar Ciputat) }\end{array}$ \\
\hline
\end{tabular}

\section{HASIL DAN PEMBAHASAN}

Berdasarkan hasil analisis, preferensi belanja konsumen potensial Pasar Ciputat cenderung tidak memilih Pasar Ciputat sebagai tujuan berbelanja dan perkembangan Pasar Ciputat diketahui tidak mengalami perubahan.

\subsection{Karakteristik Preferensi Belanja Konsumen di Kota Tangerang Selatan Berdasarkan Kedekatan Lokasi Berbelanja \\ Preferensi belanja konsumen berdasarkan} kedekatan lokasi berbelanja, dinyatakan dalam jarak yang biasanya ditempuh konsumen untuk menuju tempat berbelanja pilihannya. Konsumen umumnya memilih tempat berbelanja yang berjarak kurang dari $7.500 \mathrm{~m}$ dari tempat tinggalnya seperti yang ditunjukkan pada Gambar 1. 


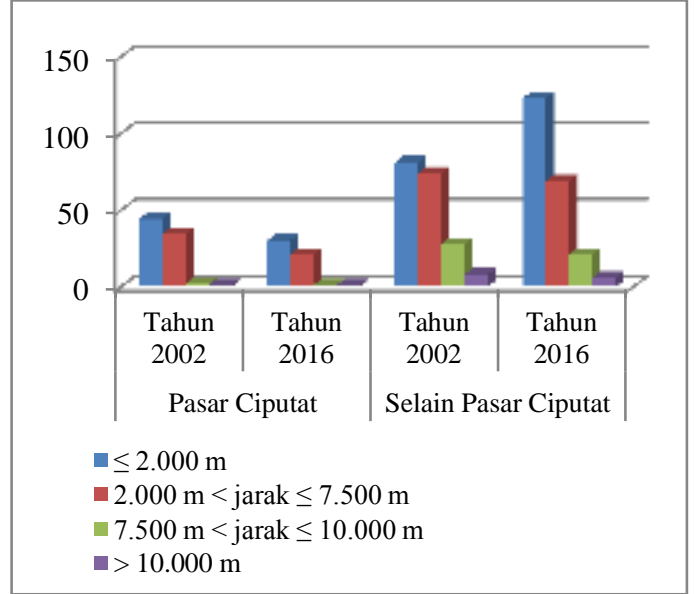

Gambar 1. Grafik Preferensi Belanja Konsumen Berdasarkan Lokasi Berbelanja

Ditinjau dari jarak tempuh menuju tempat berbelanja, konsumen cenderung memilih tempat berbelanja yang berjarak $\leq 7.500 \mathrm{~m}$ dari tempat tinggalnya, utamanya tempat berbelanja yang berada pada jarak $\leq 2.000 \mathrm{~m}$ dari tempat tinggalnya. Hal ini menandakan bahwa keberadaan tempat berbelanja yang dekat dengan konsumen semakin bertambah, sehingga konsumen tidak perlu pergi ke pasar untuk membeli barang kebutuhannya.

\subsection{Karakteristik Perkembangan Jangkauan Pelayanan Pasar Ciputat}

Dari hasil angket berupa jarak yang biasanya ditempuh konsumen menuju tempat berbelanja, diketahui bahwa konsumen yang masih memilih berbelanja di Pasar Ciputat berasal dari jarak yang dipaparkan dalam Gambar 2.

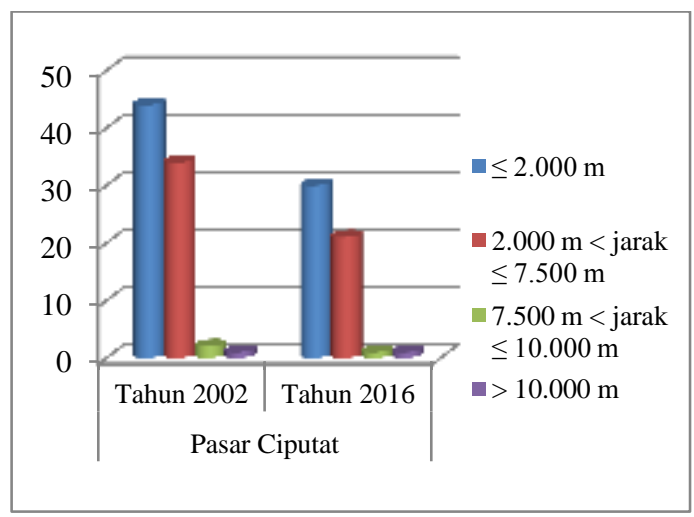

Gambar 2. Grafik Jarak Asal Konsumen Pasar Ciputat

Berdasarkan diagram tersebut dapat diketahui bahwa mayoritas konsumen Pasar Ciputat bertempat tinggal dalam radius $\leq 7.500$ $\mathrm{m}$ dari Pasar Ciputat. Hal ini sudah terjadi pada tahun 2002 hingga saat ini sehingga perkembangan jangkauan pelayanan Pasar Ciputat tidak mengalami peningkatan atau penurunan. Fakta tersebut menjelaskan bahwa jangkauan pelayanan Pasar Ciputat belum sesuai dengan arahan dari RTRW Kota Tangerang Selatan Tahun 2011 - 2031 yang mengarahkan Pasar Ciputat untuk melayani penduduk yang berjarak hingga $\geq 10.000 \mathrm{~m}$. Menurut Kotler (dalam Sukriswanto, 2012), radius pelayanan $7.500 \mathrm{~m}$ termasuk dalam klasifikasi skala pelayanan tingkat kecamatan sedangkan $10.000 \mathrm{~m}$ merupakan klasifikasi skala pelayanan tingkat kota. Hasil temuan tersebut menunjukkan bahwa Pasar Ciputat pada tahun 2002 dan 2016 hanya mampu melayani pada tingkat pelayanan kecamatan. Peta jangkauan pelayanan Pasar Ciputat pada tahun 2002 dan 2016 dapat dilihat pada Lampiran 3.

\subsection{Analisis Pengaruh Preferensi Belanja Konsumen Terhadap Perkembangan Pasar Ciputat}

Berdasarkan hasil analisis deskripsi naratif, diketahui bahwa responden yang memilih Pasar Ciputat sebagai tempat berbelanja berdasarkan kedekatan lokasi mengalami penurunan, sementara jangkauan pelayanan Pasar Ciputat yang diamati pada tahun 2002 dan 2016 tidak mengalami perubahan. Jenis pengaruh yang terjadi antara preferensi belanja konsumen berdasarkan kedekatan lokasi berbelanja terhadap perkembangan jangkauan pelayanan Pasar Ciputat adalah pengaruh III yang menjelaskan bahwa menurunnya preferensi belanja konsumen ke Pasar Ciputat berdasarkan pertimbangan kedekatan lokasi berbelanja dengan konsumen tidak berpengaruh terhadap perkembangan jangkauan pelayanan Pasar Ciputat yang stagnan.

\section{KESIMPULAN}

Pada dasarnya konsumen rumah tangga memilih tempat berbelanja yang paling dekat dengan lingkungan tempatnya bermukim sehingga konsumen rumah tangga yang berbelanja ke Pasar Ciputat pun umumnya hanya mereka yang berada pada jarak maksimal $7.500 \mathrm{~m}$ dari Pasar Ciputat, meski Pasar Ciputat dalam RTRW Kota Tangerang Selatan Tahun 2011 - 2031 diarahkan untuk menjangkau konsumen yang berada pada radius $10.000 \mathrm{~m}$ dari lokasinya berada. Menurunnya jumlah 
responden yang memilih berbelanja ke Pasar Ciputat tidak membuat jangkauan pelayanan Pasar Ciputat menyusut karena sejak periode awal beroperasi, Pasar Ciputat memang hanya mampu menarik konsumen potensial yang berada pada radius $7.500 \mathrm{~m}$ dari pasar. Akan tetapi tidak menutup kemungkinan bila jangkauan pelayanan Pasar Ciputat akan mengalami penyusutan karena adanya pengaruh faktor-faktor internal maupun eksternal lainnya yang menyebabkan konsumen potensial pada radius $7.500 \mathrm{~m}$ dari Pasar Ciputat tidak lagi memilih Pasar Ciputat sebagai tempat berbelanja.

\section{REFERENSI}

Daldjoeni. 1992. Geografi Baru Organisasi Keruangan dalam Teori dan Praktek. Bandung. Penerbit Alumni

Hidayati, Nurul. 2010. Hubungan Retail Mix dengan Preferensi Konsumen pada Tempat Berbelanja Barang Kebutuhan Rumah Tangga di Pasar Tradisional dan Pasar Modern (Berdasarkan Persepsi Konsumen di Kota Bandung)", Universitas Widyatama, Bandung.

RTRW Kota Tangerang Selatan Tahun 20112031

Sukriswanto, Ucang. 2012. Analisis Kelayakan Revitalisasi Pasar Umum Gubug Kabupaten Grobogan. Magister Teknik Sipil Universitas Diponegoro Semarang 


\section{LAMPIRAN}

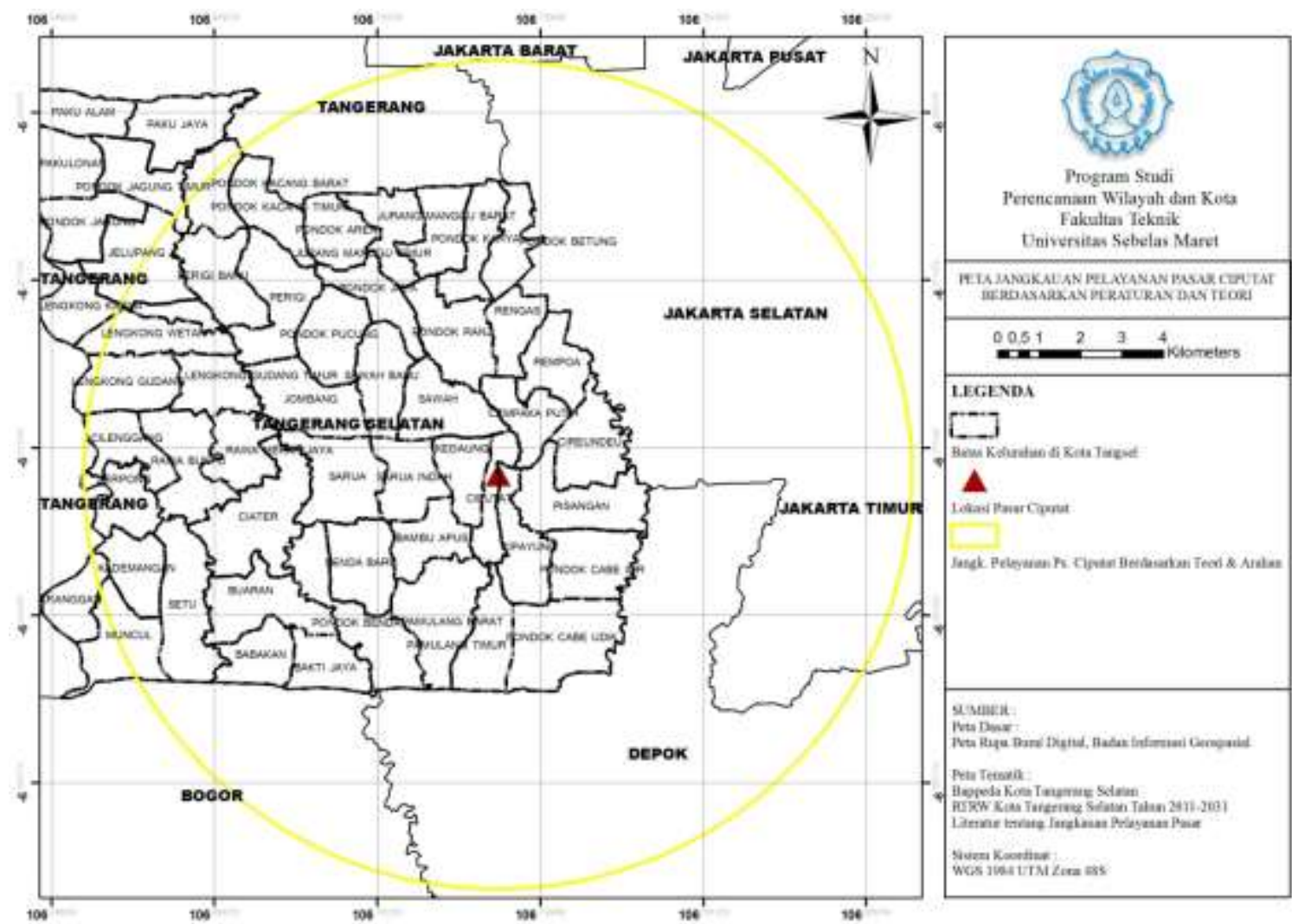

Lampiran 1. Peta Jangkauan Pelayanan Pasar Ciputat Skala Kota (RTRW Kota Tangerang Selatan Tahun 2011 - 2031) 


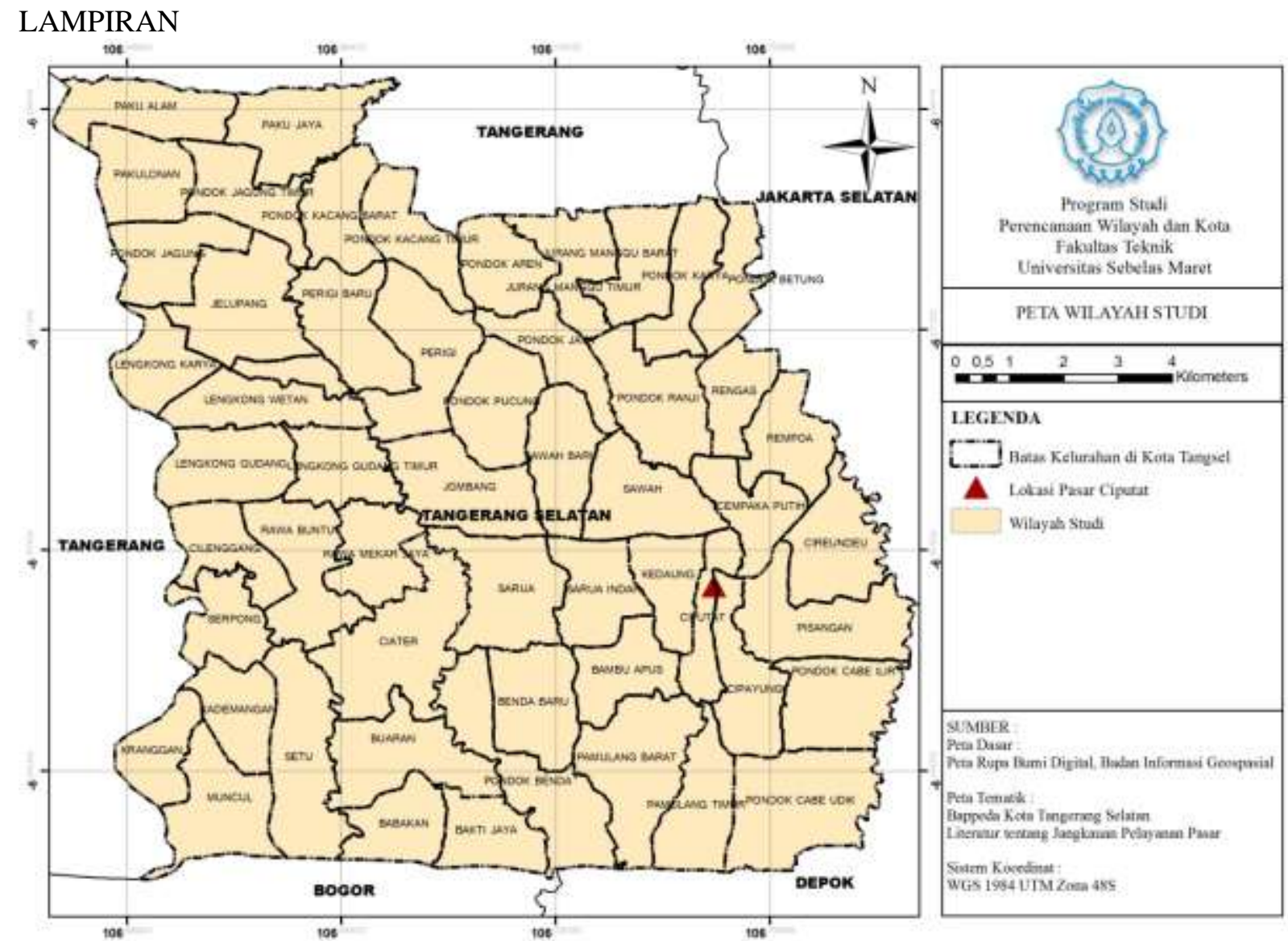

Lampiran 2. Peta Wilayah Studi

(RTRW Kota Tangerang Selatan Tahun 2011-2031) 


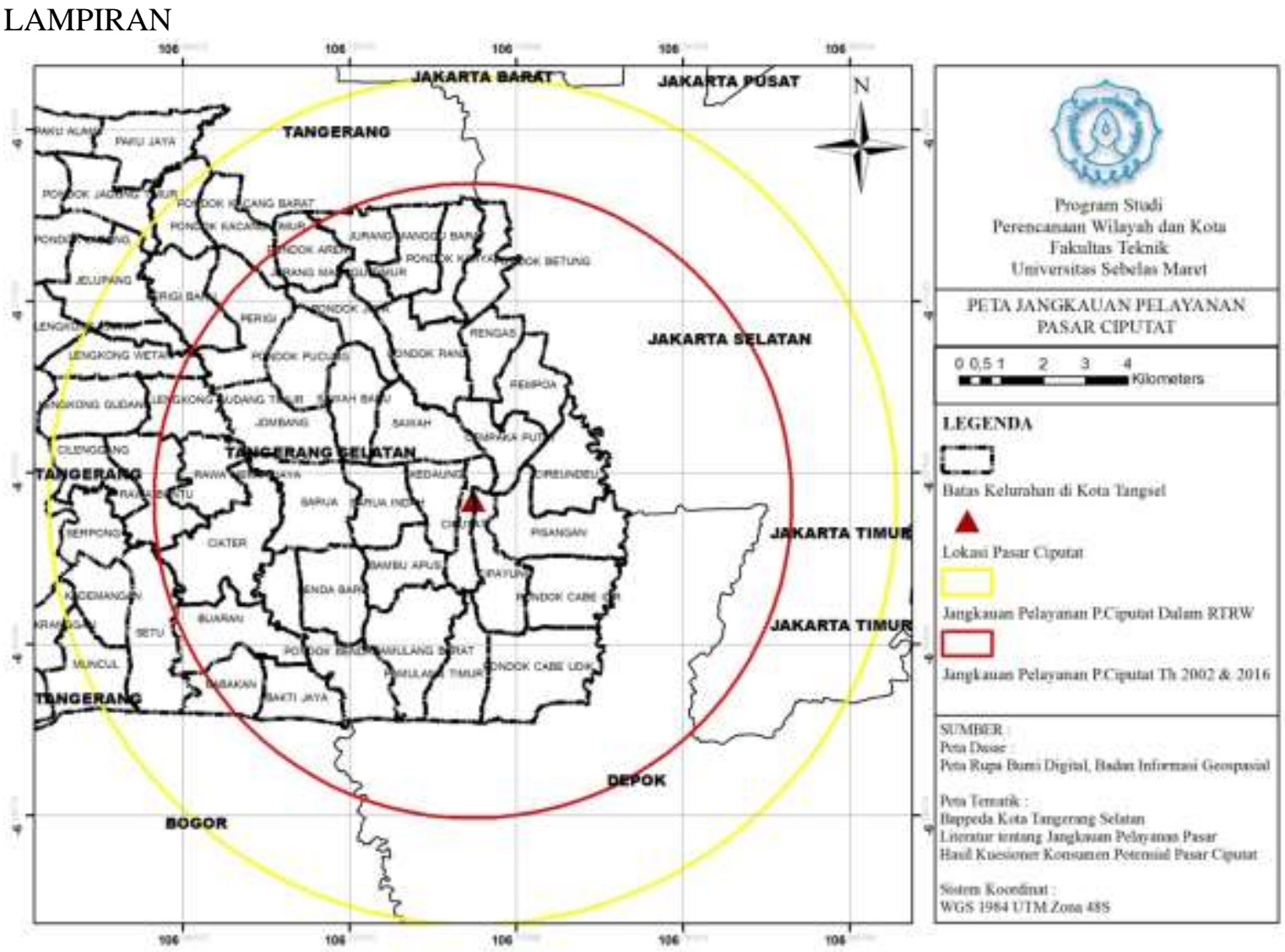

Lampiran 3. Peta Jangkauan Pelayanan Pasar Ciputat Tahun 2002 dan 2016 (Hasil Survey Lapangan, 2016) 